Portland State University

PDXScholar

Summer 2021

\title{
An Economic and Political Lens into the Lives of Undocumented Migrant Female-Headed Households
}

Fátima V. Preciado Mendoza

Follow this and additional works at: https://pdxscholar.library.pdx.edu/honorstheses

Part of the Immigration Law Commons, and the Political Economy Commons Let us know how access to this document benefits you.

\section{Recommended Citation}

Preciado Mendoza, Fátima V., "An Economic and Political Lens into the Lives of Undocumented Migrant Female-Headed Households" (2021). University Honors Theses. Paper 1137.

https://doi.org/10.15760/honors.1168

This Thesis is brought to you for free and open access. It has been accepted for inclusion in University Honors Theses by an authorized administrator of PDXScholar. Please contact us if we can make this document more accessible: pdxscholar@pdx.edu. 
Portland State University

PDXScholar

Summer 8-14-2021

\section{An Economic and Political Lens into the Lives of Undocumented Migrant Female-Headed Households}

Fatima V. Preciado Mendoza

Follow this and additional works at: https://pdxscholar.library.pdx.edu/honorstheses

Part of the Civic and Community Engagement Commons, Community-Based Learning Commons, Political Science Commons, and the Social Justice Commons Let us know how access to this document benefits you.

This Thesis is brought to you for free and open access. It has been accepted for inclusion in University Honors Theses by an authorized administrator of PDXScholar. Please contact us if we can make this document more accessible: pdxscholar@pdx.edu. 
An Economic and Political Lens into the Lives of Undocumented Migrant Female-Headed Households

Authored by:

Fátima V. Preciado Mendoza

An undergraduate honors thesis submitted in partial fulfillment of the requirements for the degree of

Bachelor of Arts

Degree from

Portland State University Honors College

and

College of Urban \& Public Affairs: Hatfield School of Government

In

Political Science

Thesis Adviser:

Dr. Brenda Glascott

Portland State University

August 5th, 2021 


\section{Acknowledgments}

I would like to acknowledge and rightfully thank the mentorship and support I received from faculty and staff throughout my time at Portland State University. My undergraduate education and student employment at the university have helped develop and refine my leadership, public speaking, analytical, and organizational skills. I thank my mentor from the Diversity Scholarship program, Karen Sayago, whose outstanding leadership, and support helped foster a welcoming, supportive community that enabled my academic and leadership growth. I am also highly grateful to my loving siblings, who have shared abundant encouragement, kindness, and unwavering support throughout my undergraduate college experience. More importantly, my experience growing up in low-income Latino neighborhoods where family members struggled to make a living instead of pursuing a college education instilled in me a desire to change the undesirable outcome my environmental surroundings were creating. My parents left Michoacán, Mexico, with some high school education and arrived in the United States as undocumented immigrants. My beautiful mother, Irma, has worked in the restaurant industry as a waitress and has experienced unlawful working conditions. She has consistently been paid less by her employer due to her immigration status. Growing up, I would often hear my mother talk about the mistreatment she experienced, which sparked my research interest to explore further the issues pertaining to America's broken immigration system. Finally, thank you to all the seven undocumented working mothers. The research participants generously volunteered their time to share their unique stories of resisting oppression and building productive and meaningful lives for themselves and their families. 


\begin{abstract}
Mexican undocumented women are essential in migrating in many households; they are often at the center of sustaining immigrant networks (Caroline B. Brettell 2015). The purpose of this study is to document, analyze, and report on the sociopolitical climate concerning the federal immigration detention and deportation pursued by the Trump regime and its effect on the mental health and financial well-being of undocumented migrant mothers working in Oregon. Throughout the interviewed data analysis process, the study examines the critical role women play in building community and navigating through multiple state social services and programs as a means of self-empowerment. This thesis argues there were increased levels of exploitation, economic and racial discrimination, and dispossession of undocumented Mexican women during this period.
\end{abstract}


An Economic and Political Lens into the Lives of Undocumented Immigrant Female-Headed Households

\section{Introduction:}

\section{Difficult Roads Often Lead to Beautiful Destinations}

Cries are piercing the gentle blue sky as I try to latch my hope onto anything around me. “Tienes que ser la niña más fuerte y valiente mañana, y cuidar de tu hermana Ariana." "You have to be the strongest, bravest girl tomorrow and take care of your sister Ariana," my mother's words swirl messily in my head as I try to breathe, just try to keep breathing, and comfort Ariana with a bag of Sabritas. I want more than anything for her to stop crying. Her mental disability and incapacity to deal with stress force me to take care of her, even though I am only four years old. The emotional trauma of being ripped away from my mother's secure arms and being driven in a car of strangers is hitting me everywhere, and I close my eyes and fade into sleep as she sweetly crunches her Sabritas. In my sleep, there is no fear, there is no open road, there is only me, my mother, and my family sharing plates of taquitos with the lullaby of Corridos enveloping us. The months before my mother finally gathered enough courage to migrate, my father had begun working a construction job in the United States. He had finally saved enough money to pay "El Coyote" and had everything prepared for the departure of his wife and children from Aguililla, Michoacán, Mexico. My mother did not accompany my siblings and me on our journey to America; instead, she needed to cross the border through underground sewage filled with dark and dirty waters. Meanwhile, long, restless nights passed until my siblings, and I finally arrived at a house in Nogales, Arizona, where my family anxiously waited for my mother's arrival. 
My parents left Michoacán, Mexico, in 2001 with partial high school educations and arrived in the United States as undocumented immigrants. They feared being deported and avoided making problems because they did not want to be separated from their children. As undocumented immigrant children, my siblings and I were encouraged to learn English and adapt to the American way of life. Hence, we practiced our English every day, but our ethnicity and immigration status in the community excluded us from what many kids could do. Growing up, it was frustrating hearing my mother say things like, “you can't play as rough as the other kids, you might break a bone," or “don't you dare catch another cold.” I now understand why my mother was so hard on us; she knew breaking a bone as undocumented children meant we would not have access to health care like other children. While I was growing up, my family and I encountered various difficulties, yet my parents held on tightly to the American dream through their consistent, tenacious work ethic. As an elementary student, I learned the value of hard work by helping my mother prepare and sell delicious Mexican pastries to the families in my neighborhood. My family and I are a part of the eleven million undocumented immigrants living in the United States whose work contributes so drastically to the success of this country's economy (Lopez et al., 2021). The tenacious work ethic of our immigrant communities drives and motivates me every day to lead with purpose, break through barriers, and thrive in the face of adversity.

\section{Purpose of Study}

For how much immigration is discussed and contested in political arenas, the history of undocumented mothers migrating to the United States is largely ignored. The focus of this paper is to inform the audience about the working conditions, mental and physical health, and safety of Mexican workers who identify as a female head of household living in the state of Oregon. I 
purposefully designed and carried out a comprehensive telephone interview process with seven undocumented mothers living and working in the Pacific Northwest. The seven unique telephone interview cases contributed an insightful narrative framework on the lived experiences of Mexican undocumented female heads of households. My initial research question focused on the role of the sociopolitical climate created by the federal immigration detention and deportation policies under the Presidential Trump regime and its effects on the mental health and financial well-being of undocumented mothers working in Oregon. Utilizing a sociopolitical perspective, my research aims to shed new light on Mexican female-headed households' "economic and social reproduction despite the appropriation of women's undervalued labor in advanced capitalist economies" (Apostolidis, 2019). Therefore, this essay offers a comprehensive data analysis of seven phone call interviews focused on the mental health and the financial and sociopolitical position of immigrant women working in Oregon. During the interviews most participants expressed concern over the worsening landscape regarding their access to employment opportunities and healthcare benefits. In addition, the interview data collected on women's working experiences demonstrates high poverty rates, limited access to healthcare, employment-related harassment, and the fear of being deported while driving. Undocumented female Mexican migrant workers perceive paid labor as a duty of motherhood. Paid employment and domestic and childcare work are intertwined with motherhood because "las Mujeres" raised in Mexico are culturally conditioned to view female paid labor as a part of motherhood. At the same time, many Chicana women feel guilty about working rather than staying home taking care of their children. Ultimately, scholars have argued that Mexican immigrant culture emphasizes employment as part of parenthood than American culture (Segura 1994). Moving forward, this essay will present a qualitative research study focused on exploring the work experiences of 
seven Latina mothers with undocumented status living in the state of Oregon. One primary theoretical framework utilized to understand the lived experiences of each participant is through the ideology of thriving together as a family, which translates to "salir adelante como familia." This ideology is rooted explicitly within the identity of immigrant mothers who strongly rely on advancing their mobility and economic success. While developing a social, political, and economic understanding of the participants' experiences, this project explicitly asks how the undocumented legal status of immigrant mothers and the current political climate concerning immigration affect their physical and mental well-being.

\section{United States History of Unauthorized Immigration}

In addition to experiencing inconsistent healthcare, undocumented immigrants have been treated unfairly through a broken immigration system that perpetuates racial discrimination, labor exploitation, unsafe working conditions, fear of driving, the terror of deportation, and lack of bilingual resources. The United States' immigration policies, for the past decade, have enforced raids, detentions, and deportation proceedings upon vulnerable immigrant communities. The historical example of the second massive wave of immigrants in the late nineteenth and early twentieth centuries arriving from Italy, eastern and southerner Europe demonstrates how this group of immigrants began experiencing political, social, and economic nativist sentiment. Primarily, with the arrival, settlement, and colonization of Europeans who in the East Coast established the 13 colonies and formed the nation and government of the United States, and as they colonized more and more territories and admitted them as states, immigration became an issue that had not existed in the same manner as before. As these colonists made their claim to the land and the colonies officially formed into a country under the US Constitution in 1776, and as large waves of immigrants in the 1820s flocked into the country, anti-immigration sentiments 
sprang up, as these people were seen as foreigners upsetting the economic, social, and political systems of the country. Therefore, the first widely spread Nativist sentiments came when "Europeans [were] driven by forces such as industrialization [from] Western Europe and the Irish potato famine [to migrate to the United States]" (Rothenberg \& Munshi 2016). As this first wave of immigrants during the colonial era from the 1880s to 1920s gained citizenship and assimilated to the American culture and governmental structures and their identities shifted to being socially viewed as American, this group became part of the future Nativist movements that feared and shunned the two following waves of large-scale immigration of Asians in the late 1800s and Hispanics in the second half of the 20th century.

In response to Italian and Eastern European large-scale immigration during the late 1840s, the first political party to directly express Nativist sentiments was created, the Know Nothing Party. This party that also reflected a much larger movement and view, promised to purify American politics by limiting or ending the influence of Irish Catholics and other immigrants, thus reflecting nativist and anti-Catholic sentiment. The party strove to restrain both immigration and naturalization; through a strong nativist sentiment derived from a religious point of view and a racist perspective. For instance, the Nativists party also viewed the Irish and Italian immigrants as a separate degraded race; there is a famous scholarly book called "How the Irish Became White" where the author discusses how an individual's race was heavily weighed into the equation of Nativists' platforms, and political attacks. The author Noel Ignatiev explains how an individual's race was strongly made more visible in the late $18^{\text {th }}$ century waves of immigration, as the individuals this time did not only have different religions, but they also looked different, had different cultures, and their ethnic features did not allow them to assimilate as quickly as the previous groups. 
Now, a critical time in history where Nativist sentiments spread nationwide was when Chinese, Japanese, and other Asian immigrants migrated to the United States, predominantly to the Western States, seeking job opportunities that needed their essential cheaply paid labor, and seeking religious freedom. Here, for the first time in the history of immigration, immigration was racialized for as, "the mining boom in the West began to subside, animosity toward the large populations of Chinese laborers and other foreigners surged, and so began a series of legislative measures to restrict immigration of certain racial groups, beginning with nationals of China" (Rothenberg \& Munshi 2016). These legislative measures included the Chinese Exclusion Act (1882), which was the first Legislative Act to halt immigration, and the Scott Act (1888). The Chinese Exclusion Act freezes the immigration of Chinese laborers for ten years, stopped the naturalization of the Chinese, and began deportations of those unlawfully residing in the country. The Scott Act, a few years later, restricted the return of Chinese nationals with lawful status into the United States. While racial exclusion expanded through the 1917 Immigration act which prohibited immigration from the "Asiatic barred zone" that covered British India, most of Southeast Asia, and nearly all the Middle East, at the same time " 27 million new immigrants arrived, mainly from Italy, Germany, Russia, Britain, Canada, Ireland, and Sweden” (Rothenberg \& Munshi 2016), showing the deep racialization of immigrants of color. And the preceding, nativist, xenophobic, quota system that restricted entry of immigrants from each country to a limited number, again, favored the White countries of Northern and Western Europe (Rothenberg \& Munshi 2016). At this time, it was evident the US government and nation was not simply opposed to immigration, they were opposed to changes in the ethnic and racial diversity of the country, attacking the national origin of primarily racial minorities. 
Equally important, the most recent wave of immigration has captured another one of the ways that the racialization of immigrants of color has been damaging and harmful to these individuals. This third post-colonial wave encapsulated Hispanics, Latinos, and those from Latin American countries. After the Bracero program in the 1960's when the US Government encouraged Latinos to come work in the states in farm labor, nativist sentiments peaked once again, and congress responded by shifting immigration policies so that the continued influx of immigrants that were still needed for work were now entering illegally, rather than legally as before (Rothenberg \& Munshi 2016). The previous discussion on the historical pattern of Nativist-fueled laws against immigrants intensifies the reality of being undocumented under unique conditions shaped through the dynamics of economies, labor markets, and wages which strongly influence why migrants move and where they move (Mavroudi \& Nagel 2016). In the last decade, political scientists have also observed a rapid change in the racial, class, and gender demographics of people entering the United States. The recent data has shown an increase in families seeking refugee status at the U.S border. In addition, women and children are fleeing violence, war, and terror in their home countries and desperately seek new opportunities elsewhere. In Oregon, the top countries of origin for immigrants include Mexico (37 percent of immigrants), China (6 percent), Vietnam (5.2 percent), India (4.1 percent), and Canada (3.6 percent) ("Fact Sheet: Immigrants in Oregon," 2017). Other studies show that immigration flows lead to more innovation and higher economic productivity. For example, when people move to the United States, they will mostly buy groceries and cars, support local restaurants and stores, rent, or buy houses, and even open their businesses and create new jobs (Simon \& Goodwin, 2018). According to the research discoveries led by the authors Mary King, Leopoldo Rodriguez, and Carrie Cobb, most Mexican-born residents in the city of Portland move back and forth 
between employment at different levels of formality, depending on their legal status, children's needs, transportation options, and other unique circumstances. At last, there are currently many industries where immigrants find employment such as agricultural fieldwork, domestic service, street vending, and day labor jobs that are "renowned for their lack of standards, and infrequent enforcement of the measures that do exist" (Apostolidis, 2019).

At this time, the public political discourse about unauthorized immigration demonstrates how facing the possibility of deportation can be one of the most stressful experiences for an individual and their family. The United States deportation statistics reflect a long history of racialized, neocolonial enforcement practices that mainly target Mexican-origin people (Achiume, 2019). For instance, the high percentage of unauthorized residents in the U.S. are of Mexican origin, approximately $58 \%$ in 2012, and deportation policies disproportionately target Mexicans and displaced people from Central and other Latin American countries (Dreby, 2012). In the early 1990s, Republicans ran on a "tough-on immigration platform", which pressured Democratic legislatures to adopt and establish restrictive positions on immigration policies. For example, according to a Vox video posted on August 2021, President Bill Clinton shattered the U.S immigration system by signing into law the Illegal Immigration Reform \& Immigrant Responsibility Act of 1996 which incentivized more individuals to stay in the United States. As described in the video, the primary purpose of the law was to decrease the number of undocumented immigrants; instead, this policy created the framework that expanded retroactive factors people could be deported for (Vox, 2021). For example, in the 1990s the threat of deportation was relatively low, people were commonly deported for committing major crimes limited to murder or trafficking. However, through the establishment of the Immigration Reform \& Immigrant Responsibility Act of 1996, with other "tough-on-immigration laws, drastically 
expanded deportable crimes to even minor infractions such as shoplifting" (Vox, 2021). This video also describes how this law created another fundamental change in the infrastructure of the U.S immigration system that forces immigrants to wait three, or ten years which made previous legal pathways through marrying a citizen, having a family member or an employer sponsor a case, now nearly impossible to obtain. The three-to-ten-year bars were intended to create punishments that were so severe to prevent people from coming into the United States. Rather than creating comprehensive solutions to fix this broken system and grant immigrant communities' lawful residence, the policy enforced massive deportations and made it even harder for people to gain legal status. After the enforcement of the 1996 immigration policy more individuals chose to remain in the United States undocumented which rapidly doubled the five million undocumented immigrants living in the country. Today, the undocumented immigration population size has doubled since according to the Migration Policy Institute (MPI), approximately 11.3 million undocumented immigrants were living in the United States between 2012-2016 (“Unauthorized Immigrant Population Profiles,” 2020). More importantly, Latin American immigrants are the dominant group in cities like Medford and Salem, with 64.8 percent and 64.5 percent of the total foreign-born population.

\section{Mexican Immigration and Displacement}

In the field of immigration studies, Mexican immigrants have been characterized as transnational people. A transnational immigrant is best described as an "individual who retains solid social ties in both sending and receiving countries while simultaneously engaging in economic projects and participating in the political life of their communities of origin and their new homes" (Fox and Rivera-Salgado 2004). In addition, the United Nations High Commissioner for Refugees website (U.N.H.C. R.) details the phenomena that may cause 
immigrants to move by explaining that individuals and their families move across international borders to improve their lives by finding work, or in some cases for education, family reunion, or other reasons. People may also move to alleviate significant hardships from natural disasters, famine, or extreme poverty. Those who leave their countries for these reasons would not usually be considered refugees under international law" (unhcr.org). The current legal structure leaves Mexican displaced people vulnerable when trying to legally cross into the United States because their experiences of displacement, from ecological degradation to cartel violence or extreme poverty, are not covered under refugee status or qualified for international protections (Cendejas, 2019). As these folks are left navigating a legal limbo that refuses to expand its categories or protections to include them, undocumented Mexicans are also left to navigate the harmful narratives media constructs about their border crossings. Consequently, the media incorrectly portray immigrants as individuals making voluntary choices about their migration and border crossing, even when more dangerous circumstances underlay their moves like gang violence, cartel violence, political corruption, famine, and poverty. Overall, Cendejas' work informs my research project by highlighting the international frameworks that Mexican migrants must navigate.

\section{Research Methods}

\section{Participant Recruitment}

The participant recruitment process for this study was secured through the snowball sampling method. The snowball sampling method uses a small pool of initial participants to help nominate others who meet the eligibility criteria for a study. The research method "snowball sampling" reflects an analogy to an increasing snowball size as it rolls downhill (Lavrakas, 2008). In this case, the research participants were recruited through Participant \#1's network of 
friends and acquittances. I conducted phone interviews with seven brave and hardworking undocumented Latinas who creatively resist oppression and build meaningful lives for themselves and their families. The research participants in this study hold different job occupations, experiences, and unique personalities that unraveled throughout the interview process. In the initial phone call to all participants, I discussed the purpose of the study and explained the methods behind the audiotaping, transcript review, confidentiality protocols, and utilizing their quotes. I also specifically asked participants about their immigration status, educational background, age, ethnicity, job occupation, and marital status. Once the research participant agreed to be interviewed, I followed up to schedule a phone call interview at the time of their choosing. I also emailed each participant a PDF copy of the consent letter with my contact information should they have additional questions. All the interviews were in Spanish, audio-recorded, and transcribed into English. The interview length ranged from thirty minutes to one hour (see Table 1 for participants demographics).

The interview questions were divided into four different inquiry sections primarily with identifying the participants' demographic information, which involved gathering data on the participant's age, ethnicity, gender, marital status, income, education, and employment opportunities. All the participants interviewed identified as Mexican immigrant women from Eastern, Southern, or Western Mexico; to maintain participants confidentiality, any reference to the participants' particular native region has been removed from the transcripts. The average age of the participants was forty-seven years. Many of the participants lived in the Willamette Valley and surrounding areas including Marion County, and Clackamas County. The women mostly had some high school education, had at least two children and were not married at the interview (see Table 1 for participants demographics). Also, the seven women interviewed reported an annual 
household income of $\$ 26,430$ or less. The average length of stay in the United States for women in the sample was 21 years. Six women worked full-time, and one woman reported being unemployed. As I facilitated the interviews, I asked detailed questions regarding participants' access to job opportunities, physical and mental health services, economic resources such as financial loans, housing assistance, and supplemental nutrition assistance programs. At last, to keep the identity of the participants confidential, names and places of employment that participants mentioned were redacted from the interview transcripts. Psychology scholars Virginia Braun and Victoria Clarke offer a narrative framework that I was able to apply to my interviews using a thematic analysis strategy which involved synthesizing the interview data by explicitly identifying themes and patterns within and across participants' experiences to explore and understand content related to the main research question. After transcribing the interview questions, I developed a discursive analytic approach by listening to the audio recording first rather than simply reading the transcripts to myself. This approach requires present and active participation with the transcripts to unravel central themes and key messages. When first listening to the interview discussion, I noticed the participants' tone of voice, length of their pauses, or rush to respond, which allowed me as the researcher to experience and "feel" the text to help gain a deeper understanding of the research material (Willig, 2008). I also repeatedly read the transcripts, marked similar sections, and observed how undocumented Latinas' intersecting identities such as gender, ethnicity, race, documentation status significantly increased their vulnerability to discrimination, criminalization, and deportation.

\section{Study Results}

The goal of the data analysis process was first to identify themes pertaining to stressors, concerns about accessing healthcare and immigrant mothers' perseverance while maintaining 
positive physical and mental health conditions and providing financially and taking care of their family members. Simultaneously, the study revealed the unique position and work environments undocumented female workers find themselves in from race discrimination, gender oppression and exploitation in their place of employment. For example, the third major theme identified across the participant experiences include feeling both empowered and economically vulnerable and feeling more anxious and stressed about the possibility of being pulled over, or worse being deported, without a driver license. More importantly, the research participants reported a conscious awareness of the importance of cultivating immigrant networks by also acknowledging the power their voices hold when expressing their political questions and priority issues.

\subsection{Experiencing Work exploitation}

The following section will look closely at the development of semi-formal labor structures relative to increasing cases of workers experiencing discrimination, wage theft, and extensively long and tiering working conditions. I first interviewed Participant \#1, who selfidentifies as an undocumented female head of household, and has worked in the restaurant industry as a waitress enduring exploitive working condition that have produced adverse physical and mental health problems. The participants shared the sacrifice of leaving their homeland behind and crossing the United States southern border regardless of the risk and danger because they envisioned a better and brighter future for their children filled with opportunity and hope that our homeland lacked. After Participant 1 crossed the U.S southern border in 2001, she worked in California for one year in a shopping center as a custodian worker and then as a waitress at multiple Mexican restaurants in Salem, Oregon. Although Participant \#1 has gradually built financial roots by specifically filing her taxes every year using an Individual 
Taxpayer Identification Number (I.T.I.N.) and purposefully forming a steady job history.

Participant \#1 has now been working in the United States without documentation for more than fifteen years. As she described her distressing and humiliating work experience because of lacking documentation status, she established a thematic narrative approach centered on the vulnerable employment situation of Mexican immigrants. Similarly, Participant \#2 is an unauthorized immigrant female with experience working in plant nurseries and restaurants. She currently makes her annual income by sewing t-shirts for a manufacturing company in Woodburn, Oregon. At the start of the second interview, the participant shared that her job involved sewing quantities of garments by working forty-five or forty-eight hours each week resulting in earrings between $\$ 800$ and $\$ 1,000$ dollars per month. At the end of the interview, the participant adds, "no matter how hard one works at the end of the day, everything for the undocumented community is more expensive. You have to work twice, even three times more, to be able to earn a living wage." At this moment, the participant's response indicates an implicit recognition of the distressing experience undocumented workers live through of working long shifts for minimal gains in return.

However, the resilient attitude of unauthorized workers is deeply rooted in their strength to resist oppression and provide for their family members, even if it requires working long hours in poorly paid jobs. Although participant number two shared that working long hours in underpaid employment made her feel exploited, she also powerfully described herself as fortunate to work, save money, pay debts, and sustain her children and family members back home. Various other workers also reported resisting overworked situations particularly in areas where the informal work structure contributed to exploitive labor conditions that exists across the United States economic infrastructure. For example, the article "II Thought It Would Be 
Different: Experiences of Structural Violence in the Lives of Undocumented Latinas," describes the blurred distinctions between formal and informal employment. First, the author points out subcontracting practices used at a hotel that supervised two staff groups where only one group was legally documented housekeepers employed directly by the hotel who earned decent wages and received benefits. The majority of the employed had undocumented status, and they received no benefits and earned less than half of the hourly rate of the other group" (Saleem, Pagan-Ortiz, Morrill, Brodt, \& Andrade, 2020). At this point, the author reveals that most participants acknowledge the abuse resulted from their lack of documentation status. This argument is proven when the author writes: “those who had papers weren't yelled at to hurry up, to do this, do that. Those of us who didn't have papers were treated so poorly. If you tried to fight back, they'd tell you to leave. When you have papers, you can argue back; you can fight if you're being fired for no reason" (Saleem, Pagan-Ortiz, Morrill, Brodt, \& Andrade, 2020). Here the author reveals the undocumented hotel workers experience a higher level of stress and violent disposition targeting undocumented workers within social and institutional structures in the place of employment.

Furthermore, Mary C. King, Leopoldo Rodriguez, \& Carrie Cobb purposefully observe employment infrastructures characterized through various attributes distinguishing formal work from informal. The article first emphasizes the key factors representing employment situations at different points in the "Spectrum of Formality," including an individual's lack of a valid social security number, the regularity and number of hours worked, and the employer's compliance with labor laws.

When investigating the distinction between levels of job formality, the authors reinforce the concept that labor laws are upheld to different degrees depending on people's legal status, ethnicity, and English proficiency. This argument is demonstrated when the authors write, 
"Though workers in semi-formal employment report many instances of violations of labor law, including safety codes ignored or overtime wages unpaid, semi-formal workers' visible relationship with an employer provide them greater protection than is true for informal workers" (King, Rodriguez, \& Cobb 2010).

Now, when conducting the telephone interview with Participant 3, I discovered she also experienced labor marginality related to her lack of legal status and limited English proficiency. In the final section of the interview, I asked the third participant if she had experienced specific forms of employment discrimination while working in the United States due to her race, sex, or immigration status. This question immediately sparked an insightful conversation on wage theft which is characterized as the illegal withholding of wages, or the denial of benefits rightfully owed to an employee. At that point, the participant shares the stressful and unfair treatment she endured while being the target of explicit abuse from a previous supervisor who treated undocumented workers poorly. She describes her experiences in more detail commenting:

“At a job I had three years ago. I faced unfair treatment due to my immigration status. I noticed that sometimes among Latinos, there is a lot of racism against one another. I think we can be extremely discriminatory against people of our race. In this situation for me at work, my supervisors supported my coworker instead of me because this person had a legal working status, and I did not. As a result, I was immediately fired and then ordered to leave the job site. Although the rest of the workers who knew about the problem supported me, the company did not, so they fired me" (Transcript \#3). 
Participant \#3 articulates the significant emotional impact of lacking legal rights and protections compared to workers with documentation status in this quote. Participant \#3 also states:

"This situation that happened to me at work made me feel very angry. I have also experienced both sadness and anger. When this specific work situation occurred, I was very enraged and irritated because I was right and the other person was in the wrong, yet because of my immigration status, I was fired from the job. But over time, I have become more aware of the reality of my undocumented legal situation. And the sad thing is that here in the United States, it does not matter who is in the right, but who holds legal status. So yes, this specific experience made me feel very angry and sad" (Transcript \#3).

Participant \#4's narrative also contributes a significant human perspective to Latinos entering the workforce. Participant \#4 shared that her family first chose to move to the Pacific Northwest in the early $20^{\text {th }}$ century where she courageously begins her journey of hard labor and describes her role as a determined working mother and contributing member of the family unit. This characteristic is especially evident in the participant's strong desire to financially provide for her children and husband despite her struggling economic situation. As an undocumented immigrant, she works at a Mexican seafood restaurant primarily as a cook and waitress for an annual income of twenty-eight thousand dollars. Over half of the participants reported working in low-income jobs due to their immigration status and lack of English proficiency. The women interviewed also indicated feeling poor, which often made them more vulnerable to exploitation. The vital notion surrounding labor exploitation is usually discussed throughout several participant complaints around underpaid work, being overworked, and experiencing unsafe working conditions or verbal abuse from employers. For example, when questioning Participant 
\#4, she firmly answered that she had experienced consistent incidents of wage theft while working in the United States. Building on the worker exploitation theme, the seventh interviewee presents an in-depth perspective on her challenges as a Mexican immigrant worker. The seventh interviewee described experiences concerning exploitation and discrimination in her place of employment. These direct worker exploitation examples can be seen in another participant's statement. According to Participant \#7:

As an undocumented worker, I am scared to advocate for myself because I fear losing my job and being deported and separated from my family. I have worked countless hours in berry fields and canneries to help provide for my family. When I chose to immigrate to this country, I never imagined I would become both a mother and a father for my children. Working in the United States has been challenging for me. I remember coming home and crying after a long workday because of the work exploitation I had experienced that day, and my heart ached because I had been away from my children all day. (Transcript\#7)

The seventh participant and her family have overcome many challenges since they migrated from the southwestern region of Oaxaca, Mexico. When the participant and her family first arrived in the summer of 2001, Participant \#7 began working temporarily in the agricultural fields. The participant currently has a consistent job at a plant nursery where she takes care of and helps harvest many plants. The participant also shares how the Covid-19 pandemic outbreak forced her employer company to lay off multiple workers. The work supervisors expected the same amount of work performed as if there were still the same number of workers before the layoffs. As a result, Participant \#7's working environment is more stressful, and there is a lot 
more pressure for the workers to work twice as hard and more efficiently. Indeed, the working conditions have impacted the amount of time Participant \#7 spends with her children because she is always working and never home. Participant \#7 is a mother of four children and is financially responsible for one older daughter who just started attending high school and two sons, fifteen and ten years old.

Another important recurring theme discussed in the seventh interview was the Mexican mothers' social and cultural expectations to perform "double duty" by taking care of the children's upbringing, cooking, cleaning, and securing employment outside of the household. With an annual income of approximately twenty-seven thousand dollars, she made sure to provide for her family, as proven by the participant when she states:

"My annual income has impacted my family structure significantly because as a mother and the primary provider at home, I have not had the opportunity to be home. A recurring and essential factor I would like to mention is that I feel like I just work to pay the rent. Daily I feel like I am only working to pay for the rent and bills and have nothing saved for a rainy day" (Transcript \#7).

At this moment, the participant's lived experiences connect with other Mexican immigrant mothers who described enduring work exploitation, marginalization, and discrimination with minimal benefits or resources in return. For this reason, I especially ask the seventh participant to expand on her personal experience combating certain forms of employment discrimination, including race, gender, and workplace safety. As evidence, the participant describes in detail how she would often witness the way supervisors discriminated against older immigrant women; group leaders yelled more harshly at the older women working, rushing them to move faster. The seventh participant strongly expressed how she hated the way 
obnoxiously rude group leaders treated the older workers. Here Participant \#7 purposefully recalled the experience of when she witnessed unfair treatment happen to one of her coworkers and courageously stepped in to help and advocate for the worker. To demonstrate, Participant \#7 further explains in the incident when she boldly states:

"Yes, one time I remember a group leader ordered my friend to carry three plants that each weighed a little over ten pounds all by herself. I had to stand up for my friend, so I got into a heated argument with this group leader and told him he was ridiculous and demanding way too much from the workers" (Transcript\#7).

At this time, the interviewee shares the struggles and strengths of Mexican laborers in the fields of the Pacific Northwest who have worked countless hours in berry fields, canneries, and forests. Now, the environmental transformation of the Pacific Northwest comes at a heavy price for agricultural workers who have endured countless types of abuse, inhumane working conditions, and wage theft. From this last case, it becomes clear that there is wage discrimination against undocumented workers in the agriculture field, particularly when the participant states:

"At my job, I have seen the way employers take advantage of their workers for not having legal papers by often paying undocumented workers less for their labor. In my experience, I have been treated less than for simply not having a social security number or a valid working visa" (Transcript\#7).

In general, the seventh interview demonstrates immigrant Oregonians' struggles and experiences navigating discriminatory practices under massively unjust and unfair working conditions. During the pandemic, multiple cases of undocumented workers across the agriculture, restaurant, retail, and construction sectors ultimately did not have access to received 
federal stimulus payment due to their legal status. In Oregon, this includes 34,000 immigrant families, predominantly Latino or Asian Americans, who specifically file their taxes using an Individual Taxpayer Identification Number (ITIN). While the seventh participant reported receiving $\$ 385.00$ each month of food stamp assistance, she also heavily expressed concern about making ends meet and supporting her children financially, especially during the months when her husband was detained and deported. At this moment, the participant emotionally expressed concern over having minimal access to financial assistance or emotional support from family and friends. Yet, she courageously mentions her children are the ones who give her the most strength and resilience to keep working. In addition, the participant first shares the traumatic incident of when her oldest son had to drive his dad to a courthouse in Lake Oswego to pay a traffic ticket. However, as soon as her son and husband stepped out of the building, I.C.E officials conducted a warrantless civil arrest by first integrating and then arresting the dad. Participant \#7 states:

Yes, that was a very traumatic situation for my children and me personally. I remember my son calling me three times crying and insisting he drop out of school to help me support the household, yet I encouraged him to stay in school. I told him that you are so close to being done, prioritize your education, and make sure to take care of you and your siblings. I told myself that we would be okay if we had enough money to pay each month's rent and bills. In this moment of crisis, I told my children not to worry about going hungry because if I was working, I would make sure to put food on the table with a roof over their heads. (Transcript\#7)

\subsection{Mental and Physical Health Insurance Concerns}


Similarly, the women in the study expressed feelings of distress and marginalization within healthcare, institutional challenges that negatively affect their sense of security and mental health needs. In comparison, Participant \#6 emphasized the need for extensive development of culturally inclusive and holistic healthcare services that effectively respond to community needs. The women's narratives reported in this paper will hopefully motivate healthcare providers, faith communities, and other allies to gain insight into what resources would be most helpful to women in alleviating some of the stressors they experience. For instance, the woman in the sixth interview also expressed significant concerns about her journey trying to acquire healthcare services. In this case, the participant shared her complex experience navigating through multiple barriers to obtain healthcare access when she states:

"In the future, I would be on board with mobilization in changing dental care for people like me. I disapprove of the current dental care services because they will give you an appointment and pay it upfront. I prefer the process at the physical care clinics where they charge you $\$ 15$ or $\$ 20$, depending on your salary. At the dentist clinic, one must be ready to pay up to $\$ 500$ or $\$ 600$ depending on the type of service at the dentist, or else they won't treat people" (Transcript \#6).

As demonstrated throughout the interview data, an individual's undocumented status strongly influences and shapes immigrants' physical and mental health conditions and safety.

More importantly, this next interview inquiry analysis section mainly focuses on evaluating social and political factors pressing down on undocumented workers who often lack health insurance. I asked Participant \#3, "what has been your experience of accessing affordable healthcare programs?" She then quickly explained she would receive a new copay balance after every doctor's visit. However, if she needed to do a blood test, she would have to pay out of 
pocket. Even though Participant \#3 has medical insurance, her medical insurance, unfortunately, does not cover any medical expenses if she were to get in an accident and need emergency care. For instance, the uninsured rate of Latinx Oregonians is twice that of the general population $12 \%$ compared to $6 \%$. Latinx Oregonians are $13 \%$ of the population but suffered $26 \%$ of the COVID cases. The "Yes on House bill 3352" grassroots campaign outlined how this bill would provide coverage to low-income Oregonians who previously didn't qualify for Medicaid because of immigration status. Medical coverage means that when people get sick, they can go to the doctor and get the care they need to keep themselves, their families, and their communities safe. In the United States there are many immigrant community members who are unable to pay for their most basic needs, so the main purpose of House Bill 3352 is to provide full medical coverage to more Oregonians, reducing uncompensated care and cost-shifting. People without insurance are less likely to see a doctor when they are sick and are more likely to delay care until they are very ill, and their care becomes very expensive. Ultimately, "Cover All People” would make healthcare coverage available to low-income undocumented adults, who are today only eligible for expensive, federally mandated emergency care. One would argue an urgent legislative priority should be to implement House bill 3352 to "Cover All People," which will reduce health disparities and medical costs and ensure all Oregonians can access preventative care and seek healthcare insurance programs in their local communities.

Furthermore, the legislative urgency to implement House Bill 3352 is especially highlighted throughout the study when the participant describes her struggle to access health services. The fifth interview questions purposefully analyze how women's economic challenges and mental health symptoms hinder access to services and resources, increasing vulnerability and 
marginalization. The women's narratives reported in this paper will hopefully motivate healthcare providers, faith communities, and other allies to gain insight into what resources would be most helpful to women in alleviating some of the stressors they experience. For example, she strongly emphasizes:

"Well, it does not cover everything. I recently had to undergo surgery, and my insurance did not cover it completely, so I still must pay it. And it's complicated, especially when it comes to dental because it is so expensive, and I wish it were made more accessible because we cannot finance charges" (Transcript\#5).

However, like the plant nursery from interview seven mentioned, some employers pay too little for workers to make ends meet and support their families. The work to advance undocumented worker rights in Oregon is far from done. In general, undocumented workers are the lowest-paid workers in the state yet perform backbreaking labor in extreme temperatures. Although immigrants, particularly people of color, have faced extreme difficulty navigating healthcare systems, the seventh participant shares a positive perspective regarding her experience accessing healthcare. For instance, she explains:

"Yes, I have a health plan through my job at the plant nursery that covers only basic doctor physical check-ups; for example, if I get sick with a cough or the flu, I can see a physician right away. I have an individual health plan for my younger three children who are U.S citizens and qualify for the Oregon Health Plan" (Transcript\#7).

As a result, the absolute impediments to accessing resources and healthcare based on individuals' immigration or class status are overtly demonstrated across all participants' stories of adversity and resilience. 


\subsection{Feeling anxious, worried, and stressed over the detention and deportation Trump regime}

In addition to workplace discrimination and financial disparities, the women described anxiety and fear because they are significantly more apprehensive about being detected and deported. The fear and anxiety that women experienced were a central part of their undocumented status, and it had negative implications on the women's ability to conduct their daily activities. This fear was heightened by the immigrant community's understanding of the presidential Trump administration's efforts to increase the deportation of undocumented immigrants. Consequently, when I asked Participant \#4 to share an example of when her migratory status had affected her ability to find a job, the participant vulnerably shared her perceptions of the political climate by stating: "It affected me very much when Donald Trump became president because it scared a lot of us undocumented people. We feared what he could do, like take away our jobs, social services, medical services. For me, that was very frustrating." (Transcript \#4). In the fourth interview the participant described being a target of explicit abuse from their supervisors and reported feeling significant anxiety about her chronic financial and employment instability. For example, one of the main themes expressed throughout Participant \#4's concluding statements was severe distress and concern about their emotional and physical well-being and overall mental health. The emotional well-being of several women in the study is negatively impacted by socio-political factors, immigration status, and life in general as an immigrant. Now, this central theme is displayed when the interviewer asks, "What emotional/ physical effect have you experienced due to your undocumented status? At this moment, Participant 4 responds by stating: "It all stems from the same thing I've said before. Since Trump took office, I have felt frustrated and stressed by thinking, "What will we do to survive in this 
country?" So, I have felt a lot of tension." The research findings from the interview with Participant \#4 centralize the participants adversity, internal anxiety and fear regarding the political climate and precisely document a collective experience of oppression and injustice when accessing state and federal services. To strengthen and validate the lived experience of the undocumented female head of households, the next paragraphs explore how the fear of deportation and economic insecurity affects working mothers' capacity to navigate past the bureaucracy of federally funded services and access social service programs like food stamps, financial aid, and housing benefits. Four of the seven women reported receiving financial assistance in the form of food stamps. At the same time, other family units steered away from applying due to the fear of exposing their personal information. For instance, this point is supported when Participant \#5 states:

We have tried to make do with what we have and leave the aid for those who genuinely need them. When you do need help, one is afraid to go and look for help because of the underlying fear that is associated with giving away so much information, and one day all that information will come to light and will hurt you the most." (Transcript \#5)

The fifth interview analysis essentially focuses on determining how an individual's immigration status and the sociopolitical climate under the Trump administration have affected the well-being of undocumented working mothers and their families. The anxiety and fear Participant 5 felt varied in intensity depending on her financial situation and the sociopolitical climate at the time. The participant shared her experience struggling to obtain secure employment when she states, "I have been stuck cleaning hotel rooms because I had no other 
choice and had to continue working to make ends meet. And financial insecurity because I would love to do so many other things but cannot because they pay so little, yet what can you do about it when you know you have no further access to employment benefits or support services." (Transcript \#5) Over half of the participants reported recurrent feelings of sadness and fear throughout their stay in the U.S. For the most part, Participant \#5's sorrow and depression stemmed from feeling unfulfilled and lacking a sense of purpose. The fifth participant expressed this sentiment strongly throughout the first few minutes of the interview. To illustrate, I expressly asked the participant to share an experience of when their immigration status had affected their employment opportunities. This question leads the participant to express her deep frustration of feeling stuck, lacking the ability to fulfill her hopes, dreams, and aspirations. For instance, the participant states: "My dream was to open a business involving food or something different. But sadly, because of my status, my aspirations were never fulfilled. For me, that is what saddens me most to have not been able to do. And from there, there is so much more like not being able to receive all the benefits of being a citizen especially now that I am unemployed, like unemployment benefits and aid when it comes to medical bills" (Transcript \#5).

\section{4 Immigrant Vulnerability}

The seven women interviewed demonstrated low education and income levels, thus creating a minimal opportunity for upward economic mobility. Additionally, working immigrant mothers are expected to perform paid and unpaid work by cleaning, cooking, and caring for their children. The harsh reality for many Mexican undocumented women seeking social services in a completely new country away from family and friends is a unique struggle filled with additional stressors such as lack of access to transportation or childcare. Even though immigrant women 
living in the United States now can safely drive and own a vehicle, this privilege has not always been granted to undocumented immigrants. For instance, the ability to drive legally is a core everyday need for many Oregon families as people take their kids to school, commute to work, and take care of family and neighbors in need. Specifically, in Oregon, tens of thousands of children are U.S citizens living with at least one parent without legal status. Now, without the ability to apply for a license to drive, parents are forced to make an impossible choice between risking arrest and deportation or choosing not to drive and being unable to care for their families. Consequently, being unable to produce a driver's license during a traffic stop is increasingly leading immigrants, who otherwise have no criminal records, to be flagged for deportation. As a result, families have been torn apart by policies focusing on enforcement and criminalizing unauthorized immigrants. For example, Participant \#5 expressed concern about living in fear of being deported or worrying about her family being torn apart simply as she travels to take her kids to school, work, or caring for family or neighbors. Like the other women interviewed, her situation was relatively common, and Participant \#5 shared living with a constant fear of driving. When I ask, "what emotional/ physical effects have you experienced due to your undocumented status?" The participant states, "Fear. More than anything, it is fear because we do not have driver's licenses and the necessity to drive. It is not out of joy to go out and drive because we go out in fear of being stopped by the police and wondering what could happen to me. You never know if you will return home.” (Transcript \#5)

Also, recent studies from the National Immigration Law center demonstrate that people with valid identification are more willing to come forward as witnesses and victims of crime and work with the police (NILC.org). That means police officers can use our limited resources on the most critical law enforcement priorities that keep our communities safe. There are currently 
thirteen states, including California and Washington, that issue driver licenses to incentivize all drivers who meet the legal, safety, insurance, identification, and residency requirements to obtain a license, regardless of immigration or citizenship status. In situations where the state and federal law denies someone a driver's license because of their immigration status forces people further into the shadows and puts immigrant friends and neighbors trying to build a better life at risk. When all drivers can apply for and obtain a driver's license, it is quicker and easier for law enforcement to verify someone's identity. In states with policies such as House Bill 2015, also recognized as the Equal Access to Roads Act, multiple universities and government studies have shown that traffic accidents and hit-and-run incidents have decreased by as much as $10 \%$ to $30 \%$ (NILC.org, February 2019). In addition, the number of insured driver rates have increased significantly, making roads safer and saving millions in out-of-pocket expenses for drivers who are not at fault. For example, under the Equal Access to Roads Act, it is against the law for state and local law enforcement to discriminate against or profile someone because they have a standard license rather than a Real ID-enhanced license. Therefore, under the new two-tier driver license system, the DMV creates a REAL ID-compliant license that Oregonians can upgrade to board a plane and enter federal buildings while maintaining a regular driver license for driving purposes only. The Oregon DMV recently implemented this new two-tier system in July of 2020.

Furthermore, reflecting on the vulnerable positions of undocumented workers, this study specifically observed that recent raids and deportations had exacerbated fears of deportation among Latino immigrants in the Pacific Northwest. As explained above, the detention and deportation of the father of Participant \#7's children revealed that deportations are a traumatic and challenging process that affects all community members. When an individual is deported, 
families are separated, and communities are disrupted. Without a doubt, I recall hearing the pain and distress behind the participant's tone of voice when she shares more about the traumatic and challenging deportation process surrounding the impact on her children's mental health and overall well-being. In this situation, the participant emphasizes the harmful effects of what happened after the children's dad was detained and deported back to his home country. For instance, the participant revealed that it impacted each of the children very differently when their father was arrested. The participant also shares how this moment traumatized her children and scarred them for life. For example, she states, "My third oldest son, Joel, would not eat any of his meals and cried so much, desperately missing his father. I would beg my son to eat, but he would refuse to eat, crying hysterically in my living room apartment, begging for his father to come home." (Transcript \#7). In general, deportation is a violent and traumatic process that significantly impacts Black people, Indigenous people, and people of color.

\subsection{Resilience}

During the Trump Administration, the federal government drastically expanded U.S. Immigration and Customs Enforcement (ICE) officers' enforcement authority (immigrantdefenseproject.org). Now, under the Trump administration, people being unable to produce a driver's license when pulled over is increasingly resulting in immigrants, who otherwise have no criminal records, to be flagged as "criminals" who are considered a "priority" for deportation. In October 2019, a New York Immigrant Defense project based on surveys with 1000 immigrant family members showed that I.C.E courthouse arrest activity had a significant negative impact on court participation and perception of the justice system (immigrantdefenseproject.org). Considering the clear evidence of the anti-immigrant campaign 
rhetoric and the racist policies associated with the Trump administration, the findings emphasize the role of structural violence through systemic institutions and governmental policies. This point mainly indicates the already established structural violence significantly amplifies undocumented women's exposure to worker exploitation and economic and racial discrimination. Furthermore, events related to the Trump administration's raids on immigrant workplaces, separating and detaining families at the border, and targeting and deporting people who had not committed serious crimes have made it challenging for immigrant communities to feel welcomed and supported. The general belief appears that if one wants to become a citizen or gain legal residency, they simply fill out and submit the paperwork, and the rest is automatic. Even though Oregonian voters might disagree about how Congress should reform the complex immigration system, we can all agree that unjust deportations without legal representation needlessly fracture families and have enormous consequences for stability and shared prosperity. For instance, every day in this country, essential undocumented workers show up. They do their part to get their families and communities through this pandemic by delivering food, working as vital health care workers, farmworkers, caregivers, and plant nursery workers. However, keeping workers in the shadows is one tool the privileged and powerful use to make immigrants vulnerable, so I firmly believe that ending this shadow economy would be better for all workers. The time is now for the United States legislatures to include a road map to citizenship for undocumented workers in the forthcoming recovery budget reconciliation process.

\section{Discussion}

Overall, the immigration system is complex, and deportations are a traumatic and challenging process very challenging to navigate alone. Therefore, we need to create more accessible, culturally responsive community-focused legal services for individuals to access. On 
behalf of people facing the prospect of deportation, research shows that an attorney's representation will help an individual remain in the country and succeed in immigration court than those who are not. In the article "Immigrants Deserve the Right to Legal Representation," the authors highlight how the U.S. immigration court system, unlike our criminal legal system, does not provide court-appointed counsel to immigrants facing deportation who are unable to afford a lawyer. For instance, "Only 37\% of all immigrants and 14\% of detained immigrants are represented by attorneys in immigration court, according to a 2016 American Immigration Council study (Sloan \& Tupper, 2021). Altogether, legal representation is crucial when participating in a trial court system because lawyers represent the professional legal players. In many cases, the lack of direct access to fair and equitable legal representation is a racial justice issue, as demonstrated in a local research project, which found that $90 \%$ of Oregonians facing deportation identified as Black, Indigenous, or people of color (Bolstad, 2019). After all, Oregon lawmakers had the opportunity to ensure a fair legal process and keep more families and communities whole. However, despite immigrant rights' groups organizing and advocacy efforts, calls to action, and the hard work from coalition partners, lawmakers failed to pass House Bill 3230 from passing, limiting the legal services support to over 7,000 Oregonians facing deportation. According to the culmination of nearly two years of deep research conducted by Goodwin Simon Strategic Research, in partnership with Causa and One Oregon:

"Employers bear the high turnover costs of hiring, training, and lost productivity when their employees are unnecessarily detained and deported. And unlawful deportations that occur when immigrants lack legal representation threaten to cost the Oregon economy $\$ 80$ million in state and local taxes paid by, and $\$ 1.4$ billion spent by, undocumented immigrants in the state each year" (Simon \& Goodwin, 2018). 
Indeed, this proves how the United States immigration system is badly broken and currently harms and poorly serves the most vulnerable individuals. At last, essential workers such as farmworkers, grocery employees, at-home caregivers, nurses, and more have played a critical role in our front-line workforce and have shown unmatched bravery and strength through the pandemic and have kept critical economic infrastructure from collapsing. Therefore, providing citizenship to essential workers is vital to recover successfully economically from the pandemic. Everyone deserves to live freely and with peace of mind, yet the immigrant community is continuously subjected to Republican-led attacks that put their lives at risk. To deliver on his promises to protect our communities from detention and deportation, President Biden must take immediate and bold action and urge Democrats in Congress to return on a pathway to citizenship for millions through reconciliation. The national immigration reform movement comprises a vast network of organizations that mobilized the community to ensure legislatures included a path to citizenship through reconciliation. There is a need for an immigration reform that grants immigrant youth, TPS holders, farmworkers, and other essential workers, protection and permanent status and would ultimately provide them access to crucial resources and formal employment opportunities.

Overall, the findings of this current study are relevant given the analysis of how these migrant women navigated through highly hostile sociopolitical environments yet still were able to demonstrate resilience by relying on social services and their familial support. First, this study adds a critical analytical dimension that is often missing in existing literature, emphasizing the vital role immigrant mothers play in building community across immigrant networks and sustaining their families as female heads of households. The women interviewed shared detailed 
insights into their experiences and limitations accessing social support services, including state and federally funded housing and food stamp assistance programs. The findings also demonstrate the interconnectedness between the key factors representing employment situations throughout the different levels of the "Spectrum of Formality," such as an individual's immigrant status, ethnicity, and level of English proficiency. In this study, the mothers working in the Pacific Northwest expressed changes in their emotional well-being, the severity of distress, and feelings of marginalization across discriminatory policies in their place of employment. The current hostile political environment and inhumane working conditions experienced by undocumented immigrants demonstrate how their lives are filled with challenges that affect their sense of security and undermine immigrant families' economic growth and employment opportunities.

In general, I have experienced firsthand similar unjust and unethical treatment immigrants, including the women interviewed in this study continue to endure. As I shared in the introductory paragraphs, my oldest sister is intellectually disabled and has suffered from epileptic seizures. Daily, my sister must take prescribed medication to control and prevent the strokes from occurring. Growing up, my siblings and I had school health insurance growing up that covered the essential physical checkups but did not cover medical expenses. My mother struggled when it came to acquiring enough income to purchase my sister's medication. Sometimes my sister was forced to go weeks without her medication. For that reason, my family needed to be ready for uncontrollable seizures. There were nights I'd wake up to my mother screaming as she watched my eldest sister have an episode. I vividly remember that my family and I would travel the city searching for resources that could provide reduced prices for my sister's medication on my mother's one day off the week. At times it was incredibly discouraging to come across more obstacles, like the lack of bilingual services. It was even more disheartening 
when we'd get denied benefits for our immigration status. Regardless, my mother persisted through the struggle and eventually found a community resource. Weeks later, my mother finally came across a program that helped needy families cover half the cost of medications. However, the price was still a financial burden for our family, and it still wasn't health insurance. Immigrants experience inconsistent care and have been mistreated because of a health system that fails to cover all working families. Nevertheless, my hardworking mother has primarily experienced racial discrimination, labor exploitation, unsafe working conditions, fear of driving, the terror of deportation, and so forth.

Over the last few years, there has been a marked increase in awareness around the need to remedy the current United States immigration policies and law systems. When Donald Trump rose to sudden political popularity and gained high ratings of social media attention, primarily throughout the anti-immigrant 2016 presidential campaign rhetoric, he ultimately normalized and exposed racism and xenophobia attitudes in various regions. However, regardless of the prevailing racist attitudes against immigrants and communities of color, lawmakers are focused on empowering individuals. For example, in the most recent legislative session, critical legislatures in Oregon especially prioritized issues such as healthcare, education, and housing programs for the undocumented immigrant community. Since undocumented immigrants are a core part of Oregon's economy, Oregon must remain a beacon of hope and freedom for immigrants and their families. The diversity of experiences and cultures enriches the nation, as immigrants participate in the long American tradition of coming to this country searching for better life and opportunities. Therefore, in collaboration with Oregon lawmakers, grassroots immigrant rights activists, I will strongly continue advocating for the modernization of the U.S 
immigration system infrastructure to ensure people have a fair and accessible way to achieve legal residency or citizenship status.

\section{Limitations and Suggestions for Future Research:}

While initially researching information on undocumented female head of households in Oregon I found very minimal information, yet I quickly discovered a comprehensive article outlining the Mental Health implications for undocumented African Migrant Women learning to access and implement their community resources. The research article sample represents only a small portion of the larger Undocumented Migrant African community, yet the authors expand on the fundamental social and political factors impacting the larger undocumented Migrant women community. My research project sample size also represents only a small portion of the larger Mexican undocumented community. Nevertheless, the snowball sampling method strategy utilized to recruit the research participants effectively allowed for the development of the interview process with the seven Mexican undocumented immigrant mothers who shared similar work experiences and cultural backgrounds. The women interviewed shared similar disparities in their community when accessing healthcare insurance, education resources, and employment opportunities. The data from the women interviewed presents an in-depth narrative data analysis of the robust and promising experiences that characterize the lives of undocumented Mexican women working in the Pacific Northwest. Finally, there is a need for future studies to examine the long-term health outcomes of immigrant women and the development of comprehensive healthcare resources that effectively provide culturally sensitive programs designed to improve the physical and mental well-being of undocumented workers. Another vital topic that future research studies should focus on is the communication messaging strategy to influence voter groups and media tactics to reinforce and distribute a more positive perception of immigrants and 
their unique narratives. When communicating about refugees, community experts have found that detailed stories about the horrors they have faced in their home countries help establish empathy for accepting them into this country. Instead of advancing the xenophobic goals of antiimmigrant opponents by repeatedly using terms like illegal immigrants, more scholarly work should start reframing the image and presence of immigrants as small business owners, innovators, students, and tenacious hard workers. Therefore, when state legislatures prioritize immigrant families, they support strong families that economically contribute more to the state infrastructures. Regardless of their social class, gender, race, or ethnicity, all immigrant families should ultimately be protected rather than torn apart.

\section{Conclusion:}

This qualitative study examines the significant lived experiences of undocumented immigrants by centering on their unique challenges accessing health care services and navigating through other forms of structural violence such as fear of deportation, workplace discrimination, and lack of economic stability. This paper's data and narrative analysis demonstrate the multifaceted forms of structural violence negatively impacting undocumented Latinas' physical and mental well-being. This groundbreaking theme is consistent with Cendejas's literature on migrant displacement discoveries showing that structural violence against Mexican immigrants without documentation operates predominantly through oppressive social policies, structures, and immigration law systems. The narratives reported in this study make visible accounts of immensely harmful and discriminatory acts against people with an undocumented status that remain unreported and unchallenged. Equally important, this study's findings purposefully help contextualize the framework of historical and ongoing racist attitudes and policies within the United States government against undocumented immigrants. The research findings also reveal 
that those living with marginalized identities related to class, race, gender, and undocumented immigration status, are likely to experience higher levels of structural violence. As a result, the challenges faced by undocumented immigrants, the aspirations of immigrants and immigrant families, and other dynamics are better understood. Throughout this research project, there is a deeper engagement and connection with each participant who forms part of Oregon families, communities, workplaces, and neighborhoods. 


\section{References:}

Achiume, E. (2019). Migration as Decolonization. STANFORD LAW REVIEW, 71(6), 15091574. Retrieved from https://escholarship.org/uc/item/8m83b98j

Apostolidis, P. (2019). The fight for time: Migrant day laborers and the politics of precarity (Studies in subaltern Latina/o politics). New York, NY, United States of America: Oxford University Press.

Bolstad, E. (2019, November 23). Oregon funds program to help Immigrants with legal aid. oregonlive.com.https://www.oregonlive.com/business/2019/11/oregon-funds-program-tohelp-immigrants-with-legal-aid.html.

Bozz Media. (2019, January). Ice out of courts. Immigrant Defense Project. https://www.immigrantdefenseproject.org/ice-courts/.

Brettell, C., and Hollifield J. F. (2015). Migration Theory: Talking across Disciplines (3rd ed). Routledge.

Braun, V., \& Clarke, V. (2006). Using thematic analysis in psychology. Qualitative Research in Psychology, 3, 77-101.

Cendejas, M.M (2019). "Moving beyond Migrant Disposability: Interrogating History and Identity" [Paper 763] (University Honors Thesis, Portland State University).

PDX Scholar, https://pdxscholar.library.pdx.edu/honorstheses/763

10.15760/honors.781

Ceres Policy Research, The Chilling Effect of ICE Courthouse Arrests: How Immigration and Customs Enforcement (ICE) Raids Deter Immigrants from Attending Child Welfare, Domestic Violence, Adult Criminal, and Youth Court Hearings, available from: https://www.immigrantdefenseproject.org/wpcontent/uploads/ice.report.exec_summ.5nov2019.pdf

Dreby, J. (2012). The Burden of Deportation on Children in Mexican Immigrant Families. Journal of Marriage and Family, 74(4), 829-845. Retrieved August 5, 2021, from http://www.jstor.org/stable/41678758

De Genova, Nicholas P. (2002). MIGRANT "ILLEGALITY" AND DEPORTABILITY IN EVERYDAY LIFE. Annual Review of Anthropology, 31(1), 419-447. https://doi.org/10.1146/annurev.anthro.31.040402.085432

Fox, J., \& Rivera-Salgado, Gaspar. (2004). Indigenous Mexican migrants in the United States. La Jolla, California: Center for U.S.-Mexican Studies, UCSD: Center for Comparative Immigration Studies, UCSD. 
Mavroudi, E., \& Nagel, Caroline Rose. (2016). Global migration: Patterns, processes, and politics. Abingdon, Oxon; New York, NY: Routledge.

Mendoza, E. (2019, May 15). Climbing the ladder: Brown politicians will not save us. Black Rose/Rosa Negra Anarchist Federation. https://blackrosefed.org/climbing-the-ladderbrown-politicians-will-not-save-us/.

Migration Policy Institute. (n. d.). Unauthorized immigrant population profiles. https://www.migrationpolicy.org/programs/us-immigration-policy-program-data-hub/una uthorized-immigrant-population-profiles

King, Mary C, Rodriguez, Leopoldo, \& Cobb, Carrie. (2010). Ni Uno Ni El Otro: The Spectrum of Formality in The U.S. Work Experience of Mexican Migrants in Portland, Oregon. Urban Anthropology and Studies of Cultural Systems and World Economic Development, 39(4), 359-395.

Lavrakas, P. (2008). Encyclopedia of survey research methods. Los Angeles, [Calif.]; London: SAGE.

Lopez, M. H., Passel, J. S., \& Cohn, D. V. (2021, April 13). Key facts about the changing U.S. Unauthorized immigrant population. Pew Research Center. https://www.pewresearch.org/fact-tank/2021/04/13/key-facts-about-the-changing-u-sunauthorized-immigrant-population/.

Luibhéid, E., Andrade R. and Stevens S. (2018). "Intimate attachments and migrant deportability: lessons from undocumented mothers seeking benefits for citizen children." Ethnic and Racial Studies, 41(1), pp. 17-35, DOI: 10.1080/01419870.2017.1286025

Saleem, Rakhshanda, Pagan-Ortiz, Marta E, Morrill, Zenobia, Brodt, Madeline, \& Andrade, Lucia. (2020). "I Thought It Would Be Different": Experiences of Structural Violence in the Lives of Undocumented Latinas. Peace and Conflict, 26(2), 171-180.

Simon, A., \& Goodwin, P. (2018). Oregon immigration Messaging guide.pdf. Google Drive. https://drive.google.com/file/d/14L5DAWkJ6YFetPOqNXyJjFLIBTjyM9Pd/view?usp=s haring.

Sloan, A., \& Tupper, L. (2021, June 6). Sloan, Tupper: Immigrants deserve the right to legal representation. https://joomlakave.com. https://pamplinmedia.com/pt/10opinion/511161-408597-sloan-tupper-immigrants-deserve-right-to-legal-representation.

The Equal Access to Roads Act, House Bill 2015, Oregon Congress (2019). https://olis.oregonlegislature.gov/liz/2019R1/Downloads/MeasureDocument/HB2015

Rothenberg, P. S., \& Munshi, Soniya. (2016). Race, class, and gender in the United States: an integrated study (Tenth edition.). Worth Publishers/Macmillan Learning. 
Relating to access to health care; and prescribing an effective date, Hous Bill 3352, Oregon Congress (2021).

https://olis.oregonlegislature.gov/liz/2021R1/Downloads/MeasureDocument/HB3352/Enr olled

Relating to taxation and prescribing an effective date, House Bill 2433, Oregon Congress (2021). https://olis.oregonlegislature.gov/liz/2021R1/Downloads/MeasureDocument/HB2433/Enr olled

Relating to universal representation; declaring an emergency, House Bill 3230, Oregon Congress (2021).https://olis.oregonlegislature.gov/liz/2021R1/Downloads/MeasureDocument/HB3 230/A-Engrossed

Trumka, R. (2018, June 21). Broken immigration system hurts working people: AFL-CIO. AFLCIO. https://aflcio.org/press/releases/broken-immigration-system-hurts-working-people.

United Nations High Commissioner for Refugees. (n.d.). 'Refugees' and 'migrants' - frequently asked questions (faqs). UNHCR.

https://www.unhcr.org/news/latest/2016/3/56e95c676/refugees-migrants-frequentlyasked-questions-faqs.html.

Vox. (2021, August 9). The law that broke US immigration. YouTube. https://www.youtube.com/watch?v=iKHl_BEsD0.

Willig, C., \& Stainton Rogers, Wendy. (2008). The SAGE handbook of qualitative research in psychology. Los Angeles: SAGE. 


\section{Appendix A}

Table 1 Demographic Characteristics of Participants:

\begin{tabular}{|c|c|c|c|c|c|c|c|}
\hline $\begin{array}{l}\text { Individual } \\
\text { Interview\# }\end{array}$ & Age & Nationality & \#Children & Education & Occupation & $\begin{array}{l}\text { Length } \\
\text { of time } \\
\text { in the } \\
\text { U.S } \\
\text { (years) }\end{array}$ & $\begin{array}{l}\text { Income } \\
\text { las } 12 \\
\text { Months }\end{array}$ \\
\hline One & 51 & Mexicana & 5 & College & $\begin{array}{l}\text { Restaurant } \\
\text { Worker }\end{array}$ & 19 & $\$ 24,000$ \\
\hline Two & 45 & Mexicana & 3 & $\begin{array}{l}\text { Middle } \\
\text { School }\end{array}$ & Day Laborer & 19 & $\$ 28,000$ \\
\hline Three & 48 & Mexicana & 3 & $\begin{array}{l}\text { Less than } \\
\text { high } \\
\text { school }\end{array}$ & $\begin{array}{l}\text { Plant } \\
\text { Nursery } \\
\text { Worker }\end{array}$ & 25 & $\$ 30,000$ \\
\hline Four & 65 & Mexicana & 7 & $\begin{array}{l}\text { Some } \\
\text { College }\end{array}$ & $\begin{array}{l}\text { Restaurant } \\
\text { Chef Worker }\end{array}$ & 23 & $\$ 24,000$ \\
\hline Five & 48 & Mexicana & 2 & $\begin{array}{l}\text { High } \\
\text { School }\end{array}$ & Unemployed & 29 & $\$ 20,000$ \\
\hline Six & 36 & Mexicana & 3 & $\begin{array}{l}\text { Some High } \\
\text { school }\end{array}$ & $\begin{array}{l}\text { Agricultural } \\
\text { Worker }\end{array}$ & 19 & $\$ 32,000$ \\
\hline Seven & 37 & Mexicana & 4 & $\begin{array}{l}\text { Middle } \\
\text { School }\end{array}$ & $\begin{array}{l}\text { Plant } \\
\text { Nursery } \\
\text { Worker }\end{array}$ & 19 & $\$ 27,000$ \\
\hline
\end{tabular}




\section{Appendix B}

\section{Interview questions for Undocumented Workers in the Pacific Northwest}

Purpose: This interview is designed to gather data on the different social factors impacting the working conditions and the mental health of Undocumented Migrant Workers who self-identify as Female Heads of Households working and living in Oregon. I will collect the research data by conducting interviews virtually (phone and using the Zoom application.) My research findings will explain how undocumented migrant women creatively draw on their life experiences to resist oppression and build meaningful lives for themselves and their families.

The research question: In Undocumented Migrant Female-Headed Households, how has an individual's citizenship status and the political climate under the current federal administration affected the well-being of undocumented migrant working mothers and their families?

Voluntary Consent: You are being asked to volunteer for a research study. It is up to you whether you choose to take part or not. If you decide to participate and stop mid-way, there will be no penalties.

How long will it take? Your participation should last around 30 minutes to an hour-long.

What will I be expected to do? You will be requested to answer a list of questions regarding your income, immigration status, age, race, educational level, job occupation, marital status, and the number of children you have. There will also be questions about your specific limitations and barriers to state-funded social services, including financial, educational resources, federal housing, food assistance programs, etc.

- *Note: I will replace your name with a pseudonym to protect your identity.

- The interview is in four parts:

\section{Part 1. Demographics}

1. Email Address, if available.

2. Phone Number

3. Name (First and Last Name)

4. Signed Consent Form

5. Do you consider yourself an Undocumented, Migrant Female Head of Household worker living in the state of Oregon?

6. How long have you lived in Oregon? 
7. Where are you initially from?

8. Identify Race/Ethnicity/

9. What is your occupation/profession/business?

10. How long have you been employed at your current job?

11. What is your approximate annual income (we know that finances can be a barrier to education opportunities and everyday survival, and that is why we would like to assess the level of income you earn)?

12. Give an example of when your immigration status has impacted your employment opportunities.

13. How many children do you have? Are you financially responsible for all of them?

14. Do you have other support systems that are not monetary (\$) (friends, family, partner, mentoring, groups, spiritual practices)?

15. What is your educational background or qualifications? (What is your degree or future academic plan)?

16. Give an example of when your immigration status has impacted your educational dreams?

17. How are you paying for school?

18. How has your annual income impacted your education, family structure, and upward mobility in this country?

\section{Part 2: Current Support Services}

The following questions will be about the support that exists within your community.

1. What has been your experience accessing affordable healthcare programs for you and your family?

2. What has been your experience accessing federally funded services and support programs like food stamps, financial aid, and housing benefits?

3. What additional community resources/support would benefit you as an Undocumented Migrant Female-Headed Household?

Part 3: Different social factors impacting the working and mental \& physical health conditions of Undocumented Migrant Workers who self-identify as Female Heads of Households.

1. In your experience working in the United States, have you experienced

1. Wage Theft - (Wage theft is defined as the illegal withholding of wages or the denial of benefits that are rightfully owed to an employee.

2. In your experience working in the United States, have you experienced specific forms of employment discrimination, including:

1. Race

2. Sex

3. Workplace safety

4. Entitlement to overtime pay

5. Family and medical leave 
3. What emotional/ phy sical effects have you experienced due to your undocumented status?

a. Fear

b. Anxiety

c. Stress

d. Sadness

e. Insomnia- (problems falling asleep, staying asleep)

f. Headaches

g. $\quad$ Chest Pain and Rapid heartbeat

h. Aches, pains, and tense muscles

i. Low energy

4. Give an example of when your immigration status has impacted your mental and emotional health?

\section{Part 4: Political Climate}

The following questions will determine how citizenship status and the current economic and political climate under the current federal administration affected the well-being of undocumented migrant working mothers and their families.

1. What difficulties have you faced due to your immigration status?

1. Problems finding secure employment

2. Financial Insecurity for education (needed to drop a term due to economic hardships, could not afford to pay for all or some classes).

3. Difficulties with Mental Health Care

4. Food and Housing Affordability

5. Safety concerns due to undocumented status such as deportation, lawyers' fees, etc.

6. Anything else? 